\title{
Applying technological organization environmental model to examine the adopting intention of e-freight for the air freight forwarder
}

Ching-Cheng Chao*, Fang-Yuan Chen**, Ching-Chiao Yang ${ }^{* * *}$, Chien-Yu Chen ${ }^{* * * *}$

\begin{abstract}
The e-freight program launched by the International Air Transport Association (IATA) has gradually become a standard specification for international air freight operations. This study examined critical factors affecting air freight forwarders' decision to adopt the IATA e-freight using a technology-organization-environment model with air freight forwarders in Taiwan as the base. Our findings show that 'information technology (IT) competence', 'trading partner pressure', 'government policy' and 'competitive pressure' all have significant positive effects on air freight forwarders' decision to adopt the e-freight and the top three factors among these are 'government funding', 'government's active promotion' and 'government's requirement of electronic air waybill (e-AWB)'. Finally, this study proposes strategies that can encourage air freight forwarders to decide on e-freight adoption for the information of relevant oK regyawniozradtison International Air Transport Association (IATA); IATA e-freight; Technology organization environment model; Air freight forwarder
\end{abstract}

Submission Date: 15/09/2015 Revision Date: 16/02/2016 Acceptance Date: 28/03/2016

* Associate Professor

Department of Shipping and Transportation Management, National Kaohsiung Marine University, 142 Hai-Jhuan Road, Nan-Tzu, Kaohsiung 811, Taiwan, R.O.C. Tel: +886-7-3617141 Ext.3156

Fax:+886-7-3647046 E-mail: chaocc@webmail.nkmu.edu.tw

** Associate Professor

Department of Transportation Technology and Management, Feng Chia University, No. 100, Wenhwa Rd., Seatwen, Taichung, Taiwan 40724, R.O.C.

*** Corresponding author: Ching-Chiao Yang

Associate Professor

Department of Shipping and Transportation Management, National Kaohsiung Marine University, 142 Hai-Jhuan Road, Nan-Tzu, Kaohsiung 811, Taiwan, R.O.C. Tel: +886-7-3617141 Ext.3166

Fax: +886-7-3647046 E-mail: yangcc@webmail.nkmu.edu.tw

**** Master

Department of Shipping and Transportation Management, National Kaohsiung Marine University, Kaohsiung 811, Taiwan, R.O.C. 


\section{Introduction}

With rapid development in technology and frequent appearance of new electronic products on the market, the past decade has witnessed tremendous growth in international air cargo transport through closely connected global supply chains. According to the Boeing World Air Cargo Forecast (Boeing, 2012), global air cargo traffic will expand at an average annual growth rate of $5.2 \%$ over the next two decades. International air cargo is an operation-intensive industry involving many participants and different specific operations. The participants include shippers, air freight forwarders,

customs brokers, cargo terminal operators, ground handling operators, and airlines. Air freight forwarders play an important role in air cargo transport activities, and are extremely important to most airlines. Many airlines even market their air freight services only through air freight forwarders, viewing them as their major customers and the main source of freight demand. Hence, the operations of air freight forwarders have a significant effect on the entire air cargo market.

Air freight forwarding encompasses various services for transport, transit, warehousing, distribution and insurance of goods consigned by cargo owners or shippers and protects shipper interests on behalf of shippers while coordinating with airlines to deliver consigned goods to their final destinations. Because of its intermediary nature in cargo transport, it is sometimes called international freight transport agency. The scope of the air freight forwarding business mainly includes export/import/transit freight transport and currently also extends to customs brokerage and inland transport. Main businesses include cargo consolidation, i.e. assembling shipments consigned by different shippers and forward them together to airlines, and/or distributing import shipments delivered by airlines to their respective consignees. The main sources of income for air freight forwarding are differences between paid and received freight charges, sales commission, high volume discounts and handling chargTehs.e air cargo industry has now widely used information technology to replace traditional operating procedures. International Air Transport Association (IATA) introduced the e-freight concept in its 2004 Simplifying the Business program. to Skyteam Cargo's 2011 report, An Introduction on e-freight, the IATA e-freight project aims to take the paper out of air cargo by creating an electronic air cargo system, which provided for the air cargo supply chain to transfer information and is expected to a standard specification for the industry (Skyteam Cargo, 2011). Many air freight forwarders have now adopted e-freight by building a cloud-based air cargo information 
system in place of the existing information system to provide the interfacing capability for airway bill transmission. This not only improves efficiency and accuracy of information transfer, but also allows them to fulfil today's corporate social of energy and carbon reduction.

According to the statistics in IATA e-freight fundamentals (2013), the traditional international air cargo operations still remain paper-based. One shipment on average generates more than 30 paper-based documents and information is transferred across those involved in air cargo transport, including consignors/shippers, ground handling agents, carriers, customs and other government agencies. Paper-based as the basic operating model not only significantly increases manual handling time, but is also noncompliant with today's demand of energy and carbon reduction. Details are shown in Fig. 1.

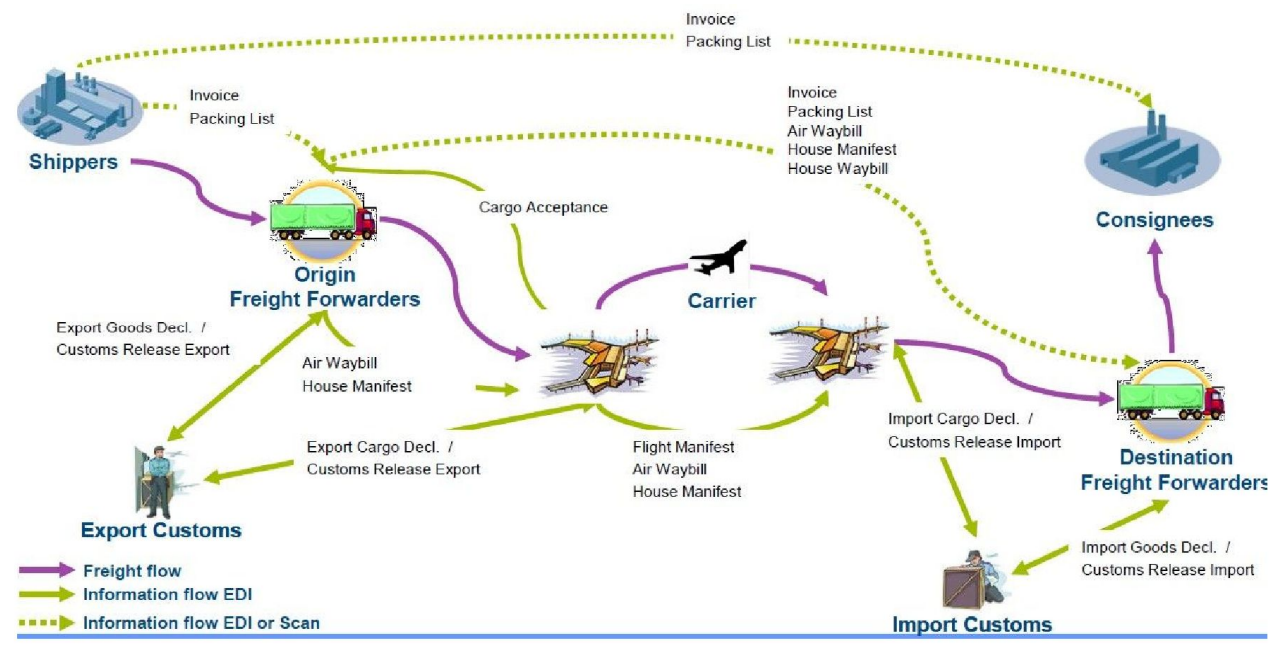

Source: IATA e-freight fundamentals 2013

IATA began to focus on improving the performance of air passenger and cargo transport with information technology in 2000 and actively promoted its Simplifying the Business (StB) program in 2004 with e-freight being one of IATA-StB core projects (and the other three being Bar Coded Boarding Passes (BCBP), Baggage Improvement

Program (BIP) and Fast Travel Program). In December, 2004, IATA Board of Governors (IATA BoG) was authorized to lead a cross-industry project, which aimed to reduce paperwork in aviation operational processes and replace existing processes to create an electronic data exchange environment that the industry and governments can trust, thereby facilitate cargo transport and information transparency. The IATA e-freight program aimed to drive operating procedures that reduce paperwork in air cargo transport by the end of 2010 with an objective across the air cargo industry led by IATA BoG to 
build the e-freight competence in the industry and develop actionable IATA e-freight operating procedures in collaboration with the industry's partners and business owners.

IATA initially implemented 16 types of electronic documents by the end of 2009 and increased the number to 20 in 2010. In the IATA e-freight program, e-freight enabled cargo without related documents is considered to be a more practical way of e-freight. In the transfer process for air cargo transport, no single paper-based document is sent, as shown in Fig. 2.

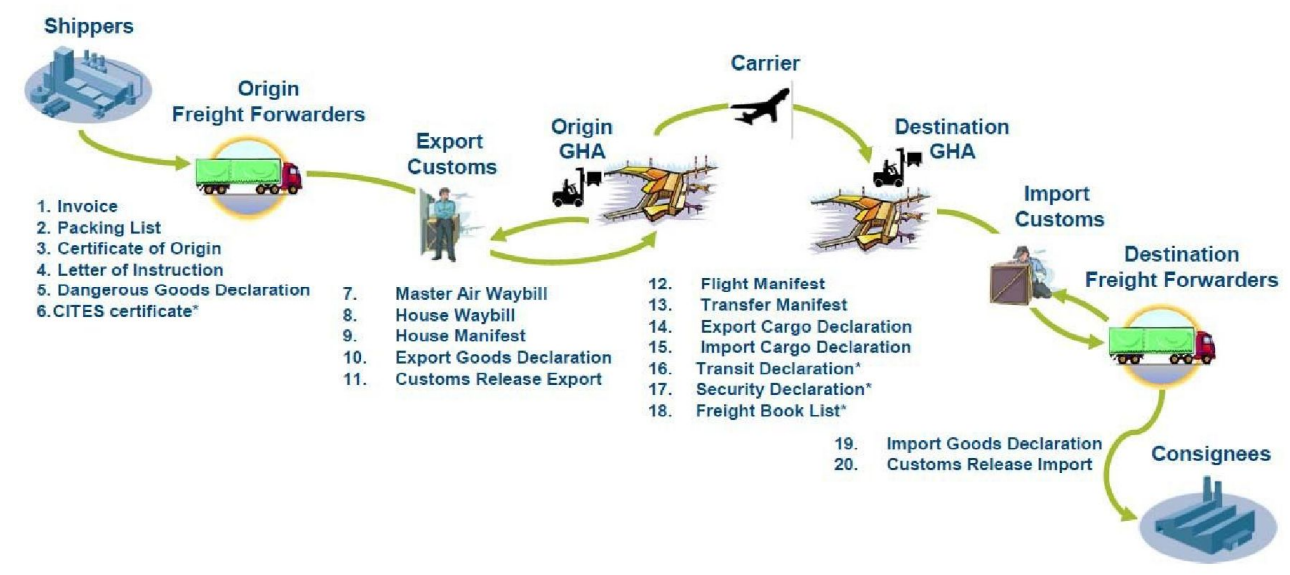

Source: IATA e-freight Handbook v4.0, 2013

Taiwan's air cargo operators were no exception. China Airlines and EVA Air officially adopted e-freight in November, 2009 and became e-freight airlines. Taoyuan International Airport and Kaohsiung International Airport also became airports in the program. However, among freight forwarders, an important part of the supply chain, those who had adopted e-freight remained the minority. Apart from few large ones, very few of the majority of air freight forwarders adopted e-freight. Despite the government's promotional efforts, their effectiveness has so far remained limited.

The technology-organization-environment (TOE) framework introduced by Tornatzky and Fleischer (1990) can affect a company's willingness to introduce new technology initiatives and use new technologies internally. The technological context refers to a company's existing IT competence and use of newly introduced technologies. The organizational context refers to its characteristics as a company, such as attributes like corporate information technology and expertise as well as globalization and top management structure. The environmental context refers to the business environment it faces, including the industries it addresses, competitors and government policies. Orlikowski (2000) suggested that the purpose of an IT system is to improve an 
organization's performance in internal operations and external competitiveness while the corporate culture and strategies in the organization's structure can both affect the adoption, introduction and integration of the IT system itself. Many studies have used the TOE framework to examine how corporate organizations introduced cross-organizational projects (Zhu et al., 2006; Zhang et al., 2007; Li et al., 2010; Wang et al., 2010; Chong and Chan, 2012; Lian et al., 2013; Lin, 2013). Table 1 outlines previous researches on the TOE framework, showing how the introduction of different information technologies was affected by different factors. This study uses Taiwan's air freight forwarders as the base and cites the TOE model to investigate from their perspective what critical factors affect their participation in the e-freight program and introduction of cloud-based air cargo information systems and provide suggestions on management for businesses and government support agencies.

\section{Table 1.}

Research on the technology-organization-environment framework

\begin{tabular}{c|c|l}
\hline Researcher & \multicolumn{1}{|c}{$\begin{array}{c}\text { Research } \\
\text { Topic }\end{array}$} & \multicolumn{1}{c}{ Variables } \\
\hline Zhu et al. (2006) & e-commerce & $\begin{array}{l}\text { Technology: relative advantage, complexity, cost and } \\
\text { security Organization: technology competence, corporate } \\
\text { size Environment: competitive pressure, trading partner } \\
\text { pressure }\end{array}$ \\
\hline $\begin{array}{c}\text { Zhang et al. } \\
\text { (2007) }\end{array}$ & Government IT & $\begin{array}{l}\text { Technology: IT infrastructures Organization: IT } \\
\text { management } \\
\text { Environment: e-government, government regulation and } \\
\text { promotion }\end{array}$ \\
\hline Li et al. (2010) & RFID & $\begin{array}{l}\text { Technology: complexity, compatibility, cost, relative } \\
\text { advantage } \\
\text { Organization: corporate size, top management support, IT } \\
\text { manpower } \\
\text { Environment: customers, suppliers, competitors, } \\
\text { governments }\end{array}$ \\
\hline Wang et al. & RFID & $\begin{array}{l}\text { Technology: relative advantage, complexity, compatibility } \\
\text { Organization: top management support, corporate size, IT } \\
\text { competence } \\
\text { Environment: competitive pressure, trading partner pressure, } \\
\text { information literacy }\end{array}$ \\
\hline
\end{tabular}




\begin{tabular}{c|c|l}
\hline Researcher & \multicolumn{1}{c}{$\begin{array}{c}\text { Research } \\
\text { Topic }\end{array}$} & \multicolumn{1}{c}{ Variables } \\
\hline $\begin{array}{c}\text { Chong and } \\
\text { Chan(2012) }\end{array}$ & RFID & $\begin{array}{l}\text { Technology: relative advantage, compatibility, complexity, } \\
\text { cost, security } \\
\text { Organization: top management support, corporate size, } \\
\text { financial resources, technology expertise } \\
\text { Environment: competitive pressure, foreseeable market } \\
\text { trends }\end{array}$ \\
\hline Ramdani et al. & $\begin{array}{c}\text { Enterprise } \\
\text { applications }\end{array}$ & $\begin{array}{l}\text { Technology: relative advantage, compatibility, complexity, } \\
\text { trialability, observability } \\
\text { Organization: top management support, corporate size, } \\
\text { organizational readiness, technology expertise Environment: } \\
\text { industries, market scope, competitive pressure, external } \\
\text { technical support }\end{array}$ \\
\hline Lin (2013) & $\begin{array}{c}\text { Electronic supply } \\
\text { chain } \\
\text { management } \\
\text { systems }\end{array}$ & $\begin{array}{l}\text { Technology: perceived benefit, adoption cost } \\
\text { Organization: corporate size, top management support, } \\
\text { ability to receive } \\
\text { Environment: trading partner influence, competitive pressure }\end{array}$ \\
\hline Cloud technology & $\begin{array}{l}\text { Technology: data protectiveness, complexity, compatibility, } \\
\text { cost } \\
\text { Organization: relative advantage, top management support, } \\
\text { adequate resources, benefit } \\
\text { Environment: government policy, perceived industry } \\
\text { pressure }\end{array}$ \\
\hline
\end{tabular}

\section{Hypotheses development}

This study cites the TOE framework to examine how the TOE factors affect the e-freight adoption by air freight forwarders in the technological, organizational and environmental contexts.

\subsection{Technological context}




\subsubsection{Complexity}

In the diffusion of innovation, a theory published by Roger (2003), complexity is defined as the degree to which the innovation is perceived as difficult to understand and use and having a negative effect upon its adoption, whereas Lian et al. (2013) suggested that human interfaces help the adoption of new technologies. The possibility that complex products may slow down or cut short adoption indicates that the ease of learning and use of new technologies has a great impact on adoption. Employees of air freight forwarders have to deal with considerably complex daily activities and have to perform services online, such as standard conversion of house manifests and waybills and trade documents, exchange of data in electronic documents, and cargo status inquiries. For those who have adopted e-freight and introduced cloud-based air cargo information systems, the time and effort required for educating and learning e-freight and associated systems or technologies will be the key considerations for the adoption of e-freight. As mentioned, this study proposes that greater complexity in the adoption of e-freight by air freight forwards will reduce the likelihood of such adoption. Therefore, this study assumes that complexity has a negative effect on the adoption of e-freight and proposes the first hypothesis as follows:

H1: Complexity has a negative effect on the adoption of IATA e-freight.

\subsubsection{Security concern}

Hoffman and Novak (1996) pointed out that the three prerequisites, security, anonymity and low transaction cost, have to be met to implement electronic transaction over the internet. Cheng et al. (2006) suggested that users become less inclined to make transactions and payments online when they perceive greater risk, indicating the importance of perceived risk to consumers. Lu et al., (2007), while exploring shipper intention toward the use of internet services provided by shipping companies, discover that security has a significant positive effect on behavioral intention. Yang and $\mathrm{Lu}$ (2012) suggested that security is one of the key factors that affect the use of e-commerce and internet services. Yiu et al. (2007) and Gunasekaran and Ngai (2008) both found in their investigations of factors affecting the use of internet banking and the intention toward the use of e-procurement in Hong Kong that perceived risk has a negative effect on intention toward use. Therefore, corporate perception of internet information security is undoubtedly an essential factor for corporate adoption of IT systems. To sum up the above mentioned arguments, this study finds that information security will be a key factor for users to decide whether to adopt e-freight or not. Based on the above analysis, this study suggests that 
security concern has a negative effect on adoption of e-freight and proposes the second hypothesis as follows:

$\mathrm{H} 2$ : Security concern has a negative effect on the adoption of IATA e-freight.

\subsubsection{Adoption cost}

Zhu et al. (2006) reported that the technology cost required for European companies to adopt e-commerce, including those for software and hardware installation and employee education and training, can actually pose obstacles to e-commerce adoption by corporate organizations. Therefore, adoption cost is one of the key factors that affect adoption of new information technologies. Wei et al. (2009) argued that adoption cost is one of the key factors that affect the development of e-commerce. Dai and Palvia (2008) found in their investigation of consumer intention toward the use of mobile commerce in China and USA that the cost factor has a significant impact on Chinese consumers, but does not affect American consumer intention toward the use of mobile commerce. Yang and $\mathrm{Lu}$ (2012) included adoption cost as one of the key factors that affect the intention toward use in their examination of the intention toward the use of port logistics information systems and define it as unable to achieve the expected benefit when the gain from the investment cannot be greater than the investment cost, resulting in that higher adoption cost lowers the intention toward use, indicating that adoption cost has a negative effect on the intention toward use. Lin (2013) examined how excessive adoption cost affects the adoption of electronic supply chain management systems by Taiwanese companies. To sum up the above mentioned arguments, this study finds that adoption cost will be a key factor for air freight forwarders to decide whether to adopt e-freight. This study hence suggests that adoption cost has a negative effect on the adoption of e-freight by air freight forwarders and proposes the third hypothesis as follows:

H3: Adoption cost has a negative effect on the adoption of IATA e-freight.

\subsection{Organizational context}

\subsubsection{Top management support}

Past studies showed that top management support has become one of the keys to project success (Caldeira and Ward 2002; Srinivasan et al., 2002; Parolia et al., 2007; Kim and Lee, 2008; Ifinedo2008; Yang and Lu, 2012). Caldeira and Ward (2002) suggested that 
the attitudes and views top management maintain regarding information technology are crucial and can contribute significantly to the development of internal IT competence (financial and human resources and user attitude) and external IT content (vendor support, product quality, service), enabling companies to achieve greater success with their IT adoption. Srinivasan et al. (2002) claimed that top management support for new technologies is given by responding to the importance of such technologies and upon the introduction of information technologies supported by top management, middle-level management will invest internal corporate resources into these new information technologies to respond to the external landscape.

Parolia et al. (2007) suggested that top management support helps improve the performance of IT projects. Kim and Lee (2008) found in their investigation of factors that affect the implementation of EDI transmissions in South Korea that top management support contributes significantly to actual EDI application, thereby helping EDI transmissions by Korean companies. Ifinedo (2008) investigated factors that affect success with enterprise resource planning (ERP) systems using the three key factors, top management support, corporate vision and external expertise and find that top management support has a positive effect on success with ERP systems, indicating that it is highly influential to the development of such systems by companies. Yang and $\mathrm{Lu}$ (2012) found in their investigation of shipping company intention toward the use of port logistics information systems that top management support has a significant positive effect on their use of such systems and management in these companies encouraging their employees to use such systems can increase employee intention to use them. Lian et al. (2013) found in their investigation of factors that affect the adoption and application of cloud technologies by Taiwanese hospitals that top management support has a positive effect on employee intention to use such technologies. To sum up the above mentioned arguments, this study infers that top management support has a positive effect on adoption of e-freight and proposes the fourth hypothesis as follows:

H4: Top management support has a positive effect on the adoption of IATA e-freight.

\subsubsection{IT competence}

Tippins and Sohi (2003) pointed out that information technology competence includes three co-specialized resources: IT objects, IT knowledge and IT operations. IT objects, also collectively known as an IT infrastructure, include software and hardware in computer systems and support manpower. They are the foundation for interdepartmental information exchange as well as critical and fundamental organizational components of an organization 
because it is necessary to maintain the normal operations of existing IT objects and develop enterprise application technologies and systems for future needs by considering what is required for organizational development. In addition, 'IT knowledge' refers to knowledge of various technologies or operations that organizations obtain from the information systems that their companies are using. Such knowledge is intangible but valuable resources of companies and taking advantage of such IT knowledge helps them build up their core business capabilities. As a result, such intangible knowledge assets are very likely to bring enormous benefits and competitive advantages to companies. IT competence is also known as IT readiness and also includes IT infrastructures and specialized IT (Zhu et al., 2006).

Wang et al. (2010) claimed that implementation of RFID applications requires introduction of new IT competences and mutual adaptation between newly introduced and existing IT systems; therefore, companies have to have more IT competences to be able to adopt new technology systems. Chong and Chan (2012) pointed out that specialized IT means possessing the knowledge and skills required for building IT applications of new technologies. This study infers that IT competence has a positive effect on adoption of e-freight and proposes the fifth hypothesis as follows:

H5: IT competence has a positive effect on the adoption of IATA e-freight.

\subsection{Environmental context}

\subsubsection{Trading partner pressure}

Hsu et al. (2006) suggested that external pressure faced by corporate operations mainly come from up- and downstream trading partners in supply chains and trading partner pressure is usually one of the key factors that drive companies to adopt new information technologies. Wang et al. (2010) argued that trading partner pressure has a positive effect on the intention to adopt REID across the supply chain in the case of the manufacturing industry. Lin (2013) claimed that trading partner pressure is one key factor for successful implementation of electronic supply chain management systems. Based on the findings of the aforementioned empirical studies, this study proposes the sixth hypothesis regarding adoption of e-freight as follows:

H6: Trading partner pressure has a positive effect on the adoption of IATA e-freight. 


\subsubsection{Government policy}

King et al. (1994) claimed that governments play a key role in IT adoption by companies and can provide funds or incentive programs that prompt companies to accelerate their new IT adoption and thereby improve their operations. Zhang at al. (2007) found in their study of the introduction of government-backed IT systems by companies in Shanghai that government regulation development and promotion play a critical role; therefore, more comprehensive government policy has a more positive effect on corporation IT adoption; in other words, government support through regulation development can motivate companies to adopt new information technologies. Lian et al. (2013) pointed out that Taiwan government's healthcare policies mainly aim to prevent waste of medical resources and the government's enforcement of the policy of electronic medical records exchange across hospitals serves as an example showing that promotion policies from governments have a positive effect on new IT adoption by companies. This study considers government policy to have a positive effect on adoption of e-freight and proposes the seventh hypothesis as follows:

H7: Government policy has a positive effect on the adoption of IATA e-freight.

\subsubsection{Competitive pressure}

Zhu et al. (2003) suggested that industry-wide competitive pressure has become one of the key factors that affect IT adoption. Lin (2013) claimed that highly competitive and increasingly unstable business environments prompt individuals or organizations to adopt innovative technologies. As market competition intensifies, companies are seeking to gain competitive advantages through innovative technologies and adopting better information technologies can greatly benefit companies (Chao et al., 2011). Companies believe that it is necessary to achieve competitive advantages through innovation and greater competitive pressure can instead motivate them to maintain their competitive advantages by adopting innovative technologies. Zhu et al. (2006) also argued that companies prompted by competitive pressure will rapidly embrace new technologies; in other words, competitive intensity, despite its initial daunting effect on new IT adoption by companies, has also the effect of driving IT internalization by companies for the purpose of maximizing IT benefits. Based on the aforementioned Based on the findings of the aforementioned empirical studies, this study proposes the eighth hypothesis regarding adoption of e-freight as follows: 
H8: Competitive pressure has a positive effect on the adoption of IATA e-freight.

\subsection{Adoption}

The theory of reasoned action (TRA) is a research model that examines how a person's behavioral intention determines his or her actual behavior from the perspective of social psychology while the intention is affected by the person's attitude toward behavior and subjective norms (Fishbein and Ajzen, 1975; Ajzen and Fishbein, 1980). Fishbein and Ajzen (1975) defined behavioral intention as the degree of willingness that a person shows to engage in a given behavior. To observe a person's positive feeling and attitude toward a given behavior, it is necessary to understand the person's intention toward that behavior.

Davis (1989), following his introduction of the Technology Acceptance Model (TAM), derives his main theory about behavior from attitude models and the theory of reasoned action (TRA). The TRA includes subjective norms that are difficult to measure due to external factors while the TAM examines how external factors affect internal belief, attitude and intention toward use. Davis (1989) argued that when consumers come into contact with new information technologies, external factors will further influence their attitudes toward and adoption of such technologies through perceived usefulness and perceived ease of use as mediator variables.

\section{Methodology}

\subsection{Research framework and variables}

This study mainly investigated the relationships between the technological (complexity, security concern, adoption cost), organizational (top management support, IT competence) and environmental (trading partner pressure, government policy, competitive pressure) contexts and adoption of e-fright by the air freight forwarding industry. The research framework is shown in Fig. 3. 


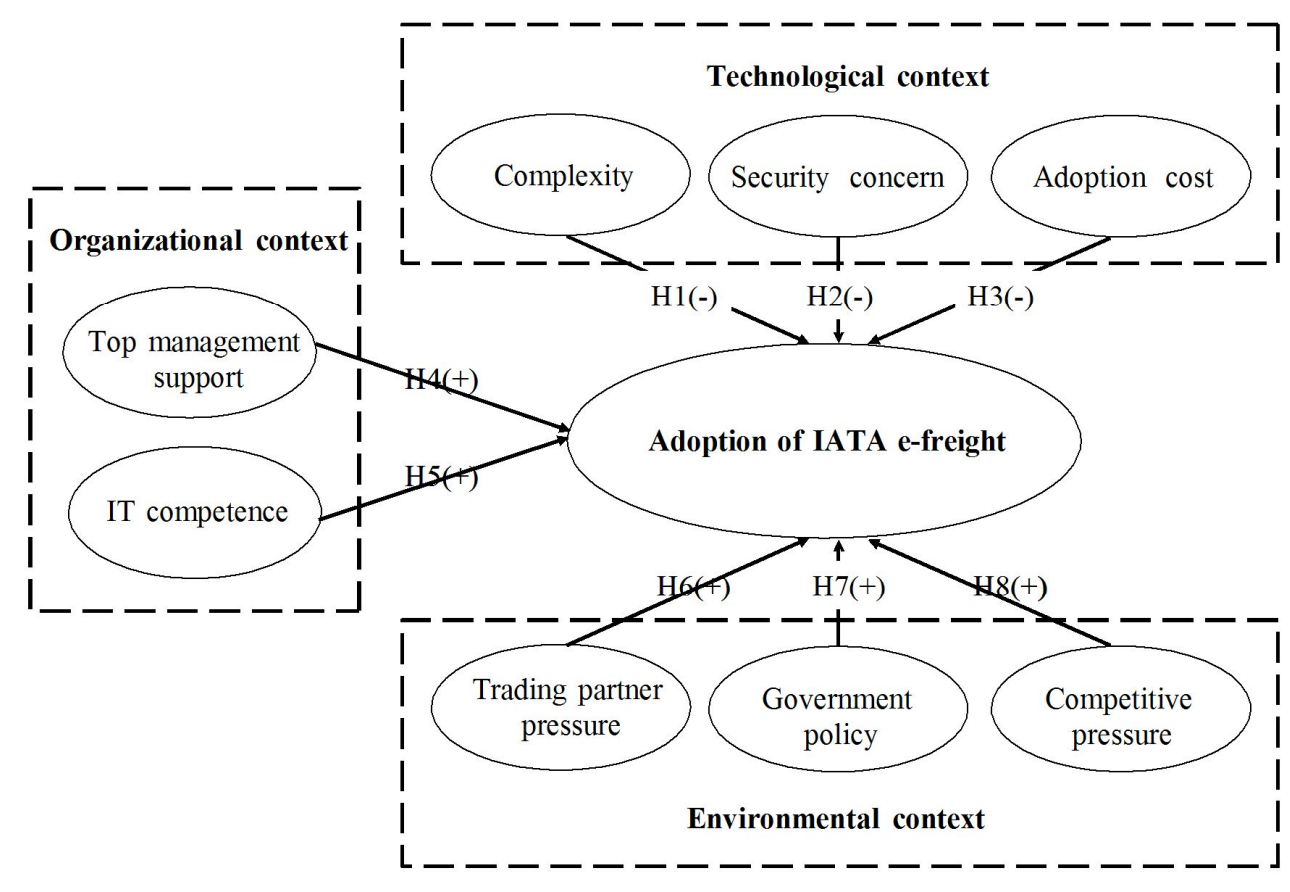

Fig. 3

Research framework

\subsection{Research variables}

This study adopted the viewpoint on complexity set forth by Wang et al. (2010): 'Increasing standard protocols and diversity in information technologies will make introduction of new information technologies an extremely complex task' and compiled four question items. Regarding security concern, the viewpoint set forth by Yang and Lu (2012): 'when companies adopt specific systems or innovative products, their existing systems or products themselves will face security threats, including the risk of leakage of important corporate and personal data' was referred to, resulting to the compilation of three question items. Regarding adoption cost, reference was made to the viewpoint set forth by Zhu et al. (2006): 'Adoption cost means the technology cost required for companies to use new information technologies, including those for hardware installation and employee education and training' resulting to the compilation of four question items. Regarding top management support, this study followed the viewpoint set forth by Ifinedo (2008): 'Top management support means the support from top management in corporate organizations for introduction of new projects or systems' and compiled four question 
items. The viewpoint on IT competence set forth by Wang et al. (2010): 'When companies implement new IT competences required for new technology or product applications, the newly introduced IT systems have to be mutually adaptable with the existing ones; therefore, companies have to have more IT competences for adoption of new IT systems' was also employed, resulting in the compilation of three question items. The viewpoint set forth by Hsu et al. (2006): 'External pressure for corporation operations mainly comes from up- and downstream trading partners in supply chains and trading partner pressure is often a key factor that prompts companies to adopt new information technologies' was also followed, resulting in the compilation of three question items. This study also adopted the viewpoint on government policy set forth by Zhang et al. (2007): 'Government regulation development and promotion play a critical role in corporate introduction of government IT systems; therefore, more comprehensive government policy has a more positive effect on corporation IT adoption; in other words, government support through regulation development can motivate companies to adopt new information technologies' and compiled three question items. Regarding competitive pressure, Chao et al. (2011) pointed out, 'As market competition intensifies, companies are seeking to gain competitive advantages through innovative technologies and adopting better information technologies can greatly benefit companies', which gave rise to the compilation of two question items. Regarding adoption, Fishbein and Ajzen (1975) claimed, 'Behavioral intention means the degree of willingness that a person shows to engage in a given behavior. To observe a person's positive feeling and attitude toward a given behavior, it is necessary to understand the person's intention toward that behavior.' This study converted this viewpoint to the corporate perspective for the measurement of adoption and compiled three question items. All the question items in our survey were measured using a 7 point Likert scale. These and their references are outlined in Table 2.

Table 2.

Measurement of research variables and references

\begin{tabular}{l|c}
\hline \multicolumn{1}{c|}{ Variable/Item } & Reference \\
\hline Complexity (CM) & \\
CM1. Adopting e-freight is a complex process. \\
CM2. Our company's computer system is not exactly compatible with \\
e-freight. \\
$\begin{array}{l}\text { CM3. Adopting e-freight is not consistent with our company's values and } \\
\text { beliefs. }\end{array}$ \\
$\begin{array}{l}\text { CM4. It is difficult to incorporate e-freight into our company's current } \\
\text { operational practices. }\end{array}$ \\
\hline
\end{tabular}




\begin{tabular}{l|l}
\hline Variable/Item & Reference \\
\hline Security concem $(\mathrm{SC})$ &
\end{tabular}

Security concern (SC)

$\mathrm{SC} 1$. Adopting e-freight is not safe for our operating environment.

Lu et al. (2007);

$\mathrm{SC} 2$. The operating model of e-freight is not protected by law. SC3. The

Yang and $\mathrm{Lu},(2012)$ security measures in e-freight are not perfected.

\section{Adoption cost (AC)}

AC1. Adopting e-freight has a build cost greater than its benefit.

$\mathrm{AC} 2$. Adopting e-freight has an operating cost greater than its benefit.

AC3. Our company thinks that adopting e-freight requires a fairly high cost for employee training.

Zhu et al.(2006);

Li et al. (2010);

Chong and Chan(2012)

A4C. Adopting e-freight yields an overall benefit less than its cost.

\section{Top management support (TM)}

TM1. Our company's top management is highly interested in adopting e-freight.

TM2. Our company's top management will actually participate in the adoption of e-freight.

TM3. Our company's top management recognizes that adopting e-freight can improve business performance.

TM4. Our company's top management will consider the adoption of e-freight as our company's key development strategy.

Kim and Lee (2008); Ifinedo (2008);

Yang and $\mathrm{Lu}(2012)$

\section{IT competence (TC)}

TC1. Our company's information infrastructure can be used in support of the adoption of e-freight.

TC2. Our company will be committed to training our employees on knowledge required for the adoption of e-freight.

Jain et al. (2009);

Wang et al.(2010)

TC3. Our employees already have the skills required for the adoption of e-freight.

\section{Trading partner pressure (TP)}

TP1. Airlines strongly recommend us to adopt e-freight.

TP2. Shippers strongly recommend us to adopt e-freight.

TP3. Customs brokers or depot operators strongly recommend us to adopt

Hsu et al.(2006);

$\operatorname{Lin}(2013)$ e-freight.

\section{Government policy (GP)}

GP1. We will adopt e-freight if our government requires e-AWB.

GP2. We will adopt e-freight if our government actively promotes it.

GP3. We will adopt e-freight if our government funds it.
Zhang atal.(2007);

Lian et al. (2013) 


\begin{tabular}{|c|c|}
\hline Variable/Item & Reference \\
\hline $\begin{array}{l}\text { Competitive pressure (CP) } \\
\text { CP1. Adopting e-freight is a necessity in our company's business strategy. } \\
\text { CP2. Adopting e-freight can increase our company's competitiveness. } \\
\text { CP3. Not adopting e-freight may lead to customer loss. }\end{array}$ & $\begin{array}{c}\text { Chao et al. (2011); Zhu } \\
\text { et al. (2006) }\end{array}$ \\
\hline $\begin{array}{l}\text { Adoption (AD) } \\
\text { AD1.Our company's procedures require the adoption of e-freight. } \\
\text { AD2. Our company is willing to adopt e-freight. } \\
\text { AD3. We will recommend our trading partners (e.g. airlines, customs } \\
\text { brokers or terminal operators) to adopt as well. }\end{array}$ & $\begin{array}{c}\text { Fishbein and } \\
\text { Ajzen(1975); Ajzen and } \\
\text { Fishbein (1980) }\end{array}$ \\
\hline
\end{tabular}

\subsection{Research design}

The survey base was air freight forwarders in Taiwan and the population came from the member directories of Taipei Airfreight Forwarders \& Logistics Association of Taiwan (TAFLA) and Kaohsiung Airfreight Forwarder's Association (KAFA). The main source of the questionnaire content was our literature review, which determined dimensions and questions. Any inappropriate parts were then modified based on the results of expert interviews to finalize the first draft. The questionnaire content included two parts. Part 1 was for the respondents to provide their profile information and a summary on their adoption of IATA e-freight; and Part 2 was for surveying factors that affect their adoption of IATA e-freight. To avoid semantic ambiguities that mislead the respondents to provide wrong answers, the first draft underwent a pretest and subsequent modifications by experts on air cargo transportation from the industry, government and academia for increased reliability and validity of the questionnaire. Sample data were collected via a survey, for which the questionnaires were mailed to the respondents. The collected data were analyzed using SPSS and the methods involved included descriptive statistics, reliability and validity analysis, Pearson correlation analysis, and multiple regression analysis. 


\section{Results}

\subsection{Samples}

For this study, a general survey was conducted on the managers from 1088 air freight forwarders who were members listed in the directories of TAFLA and KAFA between April and June, 2014. After eliminating 17 questionnaires that were found to be incomplete from the in total 166 collected, 149 were valid, accounting for the recovery rate of $13.7 \%$. According to the statistical analysis in Table 3, more than half of the respondents $(81.2 \%)$ were in management, supporting the reliability of the data collected for this study. Regarding years of service in air freight related businesses among the respondents, '21 years or more' had the highest percentage at $49.0 \%$ and together with ' 11 years or more' constituted $77.9 \%$, indicating that the respondents were mostly senior staff and had a certain level of knowledge of the air freight sector.

Regarding years since founding of the respondents' companies, '21 years or more' constituted $57.1 \%$. Regarding number of employees, ' $31-100$ ' constituted $32.2 \%$ and ' 101 or more' $29.5 \%$. Regarding annual turnover, 'NT\$100-499 million' had the highest percentage, accounting for $26.2 \%$ of the overall sample size, and 'NT $\$ 500$ million or more' constituted $20.1 \%$.

Table 3.

Respondent profiling

\begin{tabular}{l|rr|l|r|r}
\hline Profile attribute & $\begin{array}{c}\text { No. of } \\
\text { respondents }\end{array}$ & $\begin{array}{c}\text { Ratio } \\
\text { (\%) }\end{array}$ & Profile attribute & $\begin{array}{c}\text { No. of } \\
\text { respondents }\end{array}$ & $\begin{array}{c}\text { Ratio } \\
\text { (\%) }\end{array}$ \\
\hline Title & & & Years of service in air freight & & \\
Deputy Manager & 41 & 27.5 & 5 years or less & 8 & 5.4 \\
Assistant Manager & 72 & 4.4 & 6-10 years & 25 & 16.8 \\
Deputy Manager & 3 & 2.0 & $11-15$ years & 19 & 12.8 \\
Section Chief & 5 & 3.4 & 21 years or more & 24 & 16.1 \\
Director & 7 & 4.7 & Turnover (NTS million) & 73 & 49.0 \\
Sales & 2 & 1.3 & $<5$ & 8 & 5.4 \\
Site Operator & 11 & 7.4 & $5-9$ & 12 & 8.1 \\
Others & & &
\end{tabular}




\begin{tabular}{|c|c|c|c|c|c|}
\hline Profile attribute & $\begin{array}{c}\text { No. of } \\
\text { respondents }\end{array}$ & $\begin{array}{c}\text { Ratio } \\
(\%)\end{array}$ & Profile attribute & $\begin{array}{c}\text { No. of } \\
\text { respondents }\end{array}$ & $\begin{array}{c}\text { Ratio } \\
(\%)\end{array}$ \\
\hline Years of establishment & & & $10-29$ & 12 & 8.1 \\
\hline 2 years or less & 2 & 1.3 & $30-49$ & 27 & 18.1 \\
\hline $3-5$ years & 12 & 8.1 & $50-99$ & 21 & 14.1 \\
\hline 6-10 years & 8 & 5.4 & $100-499$ & 39 & 26.2 \\
\hline $11-15$ years & 18 & 12.1 & $>500$ & 30 & 20.1 \\
\hline $16-20$ years & 24 & 16.1 & Number of subsidiaries & & \\
\hline $21-30$ years & 43 & 28.9 & 2 or less & 37 & 24.8 \\
\hline 31 years or more & 42 & 28.2 & $3-5$ & 26 & 17.4 \\
\hline Number of employees & & & $6-10$ & 20 & 13.4 \\
\hline 10 or less & 30 & 20.1 & $11-15$ & 11 & 7.4 \\
\hline $11-30$ & 27 & 18.1 & $16-20$ & 11 & 7.4 \\
\hline $31-50$ & 26 & 17.4 & $21-25$ & 8 & 5.4 \\
\hline $51-100$ & 22 & 14.8 & 26 or more & 36 & 24.2 \\
\hline $101-400$ & 20 & 13.4 & & & \\
\hline $401-700$ & 9 & 6.0 & & & \\
\hline 701 or more & 10 & 10.1 & & & \\
\hline
\end{tabular}

\subsection{Analysis of respondent perception in terms of TOE and adoption}

First, statistical analysis was performed on respondent perception in the questions of all the dimensions. Responses to these questions were measured using a 7-point Likert scale $(1$ = strongly disagree; 2 = moderately disagree; 3 = slightly disagree; $4=$ neutral; $5=$ slightly agree; $6=$ moderately agree; and $7=$ strongly agree). A higher average score in all the questions means the respondent is more agreeable to the dimensions including complexity, security concern, adoption cost, top management support, IT competence, trading partner pressure, government policy, competitive pressure and adoption. In contrast, a lower average score denotes lower respondent agreeableness.

As shown in Table 4, the respondents' current agreeableness to IATA e-freight scored on average between 5.872 and 3.503. The top five items with highest agreeableness are: 'we will adopt IATA e-freight if our government funds it'; 'we will adopt IATA e-freight if 
our government actively promotes it'; 'we will adopt IATA e-freight if our government requires e-AWB'; 'adopting IATA e-freight is a necessity in our company's business strategy'; and 'our company is willing to adopt IATA e-freight' (each with an average score higher than 5.4). This also shows that the air freight forwarders now urgently need government support and promotion to adopt IATA e-freight.

The bottom five items with lower average scores are: 'adopting IATA e-freight is not safe for our operating environment'; 'our company's computer system is not exactly compatible with IATA e-freight'; 'adopting IATA e-freight is a complex process'; 'adopting IATA e-freight yields an overall benefit less than its cost.'; and 'adopting IATA e-freight is not consistent with our company's values and beliefs'. This result shows that the negative items have relatively lower scores, indicating that the air freight forwarders perceive it safe to adopt IATA e-freight. A possible explanation is that no complexity involved in the adoption process causes the air freight forwarders to perceive no risk and cost issues.

Table 4.

Descriptive statistics results

\begin{tabular}{cccccccc}
\hline Item & Mean & S.D. & Rank & Item & Mean & S.D. & Rank \\
\hline GP3 & 5.872 & 1.152 & 1 & SC2 & 4.651 & 1.581 & 16 \\
GP2 & 5.779 & 1.132 & 2 & TM1 & 4.631 & 1.170 & 17 \\
GP1 & 5.530 & 1.206 & 3 & CP3 & 4.624 & 1.540 & 18 \\
CP1 & 5.430 & 1.347 & 4 & AC2 & 4.591 & 1.602 & 19 \\
AD & 5.423 & 1.140 & 5 & TP3 & 4.570 & 1.526 & 20 \\
AD3 & 5.403 & 1.304 & 6 & AC & 4.490 & 1.464 & 21 \\
CP2 & 5.362 & 1.164 & 7 & TC3 & 4.483 & 1.478 & 22 \\
AD1 & 5.161 & 1.452 & 8 & TM3 & 4.456 & 1.579 & 23 \\
TC1 & 5.094 & 1.332 & 9 & TP2 & 4.362 & 1.565 & 24 \\
SC3 & 4.906 & 1.637 & 10 & CM4 & 4.349 & 1.656 & 25 \\
TP1 & 4.832 & 1.495 & 11 & SC1 & 4.329 & 1.706 & 26 \\
TC2 & 4.826 & 1.497 & 12 & CM2 & 4.295 & 1.621 & 27 \\
AC1 & 4.765 & 1.508 & 13 & CM1 & 4.282 & 1.452 & 28 \\
TM4 & 4.745 & 1.507 & 14 & AC4 & 4.027 & 1.470 & 29 \\
TM2 & 4.718 & 1.316 & 15 & CM3 & 3.503 & 1.459 & 30 \\
\hline
\end{tabular}




\subsection{Reliability analysis}

Reliability analysis was further performed to measure internal consistency and credibility of each dimension. Cronbach's a and overall corrected item-total correlation coefficient values served as the basis to eliminate items without internal consistency. A higher Cronbach's a value indicates higher reliability. It is generally required that a reliability value must be greater than 0.7 and overall corrected item-total correlation coefficient value must be greater than 0.4 (Hair et al., 2009). Table 5 shows that each dimension regarding IATA e-freight has an alpha value greater than 0.7 and the overall corrected item-total correlation coefficient is greater 0.5 , indicating excellent reliability.

Table 5.

Reliability analysis of all the dimensions regarding IATA e-freight

\begin{tabular}{c|c|c|c|c}
\hline Variable & Mean & S.D. & Cronbach's $\alpha$ & Corrected item - total correlation \\
\hline $\mathrm{CM}$ & 4.058 & 1.260 & 0.840 & $0.584-0.779$ \\
\hline $\mathrm{SC}$ & 4.610 & 1.506 & 0.921 & $0.771-0.911$ \\
\hline $\mathrm{AC}$ & 4.430 & 1.366 & 0.921 & $0.771-0.856$ \\
\hline $\mathrm{TM}$ & 4.586 & 1.166 & 0.850 & $0.546-0.852$ \\
\hline $\mathrm{TC}$ & 4.754 & 1.289 & 0.872 & $0.739-0.780$ \\
\hline $\mathrm{TP}$ & 4.540 & 1.383 & 0.880 & $0.653-0.882$ \\
\hline $\mathrm{GP}$ & 5.718 & 1.057 & 0.879 & $0.697-0.880$ \\
\hline $\mathrm{CP}$ & 5.120 & 1.170 & 0.813 & $0.655-0.696$ \\
\hline $\mathrm{AD}$ & 5.319 & 1.156 & 0.840 & $0.659-0.828$ \\
\hline
\end{tabular}

\subsection{Effects of TOE factors concerning air freight forwarders on adoption}

\subsubsection{Correlation analysis}

To have an initial understanding of whether correlations exist between factor dimensions, the mean value in each dimension was used for Pearson Product-moment correlation analysis. The results show that each factor dimension achieved significant highly positive correlations both when the significance level was 0.05 and 0.01 , as shown in Table 6. In this correlation matrix concerning IATA e-freight, it is mainly notable that the independent variables 'complexity', 'security concern' and 'adoption cost' have no correlations with the dependent variable 'adoption'. 
Table 6.

Pearson correlation matrix

\begin{tabular}{|c|c|c|c|c|c|c|c|c|c|}
\hline & AD & $\mathbf{C M}$ & SC & $\mathrm{AC}$ & TM & $\mathrm{TC}$ & TM & GP & CP \\
\hline $\mathrm{AD}$ & 1.000 & & & & & & & & \\
\hline $\mathrm{CM}$ & -0.111 & 1.000 & & & & & & & \\
\hline $\mathrm{SC}$ & 0.010 & $0.708 * *$ & 1.000 & & & & & & \\
\hline $\mathrm{AC}$ & -0.100 & $0.771 * *$ & $0.731^{* *}$ & 1.000 & & & & & \\
\hline TM & $0.440 * *$ & $-0.430 * *$ & $-0.444 * *$ & $-0.411 * *$ & 1.000 & & & & \\
\hline TC & $0.593 * *$ & $-0.286 * *$ & -0.082 & $-0.176 *$ & $0.543 * *$ & 1.000 & & & \\
\hline TM & $0.497 * *$ & $-0.171 *$ & $-0.226 * *$ & $0.305 * *$ & $0.463 * *$ & $0.410^{* * *}$ & 1.000 & & \\
\hline GP & $0.671 * *$ & $-0.300 * *$ & $-0.169 *$ & $-0.177^{*}$ & $0.481 * *$ & $0.549 * *$ & $0.371^{* *}$ & 1.000 & \\
\hline GP & $0.666^{* *}$ & -0.051 & 0.104 & -0.022 & $0.444 * *$ & $0.466^{* *}$ & $0.371^{* *}$ & $0.542^{* *}$ & 1.000 \\
\hline
\end{tabular}

Note: * means when the significance level is 0.05 ; and $* *$ means when the significance level is 0.01 .

\subsubsection{Multiple regression analysis}

Multiple regression analysis was also used. Prior to this, each factor was first subjected to a variance inflation factor (VIF) test. A VIF value greater than 10 indicates possible collinearity between the independent variables. For the multiple regression analysis regarding IATA e-freight, the VIF values of all the factor dimensions were between $1.510-3.319$, i.e. less than 10 , indicating no collinearity between the independent variables. Therefore, the data was suitable for multiple regression analysis.

Following the regression analysis, as can be seen in Table 7, all the DW (Durbin Watson) statistics are between 1.5 2.5, indicating no residual autocorrelation and the significant effect of the model in which the air freight forwarders adopt IATA e-freight with an overall explanatory power up to $65.6 \%$ pertaining to adoption. Of all the factors, IT competence, trading partner pressure, government policy and competitive pressure have significant positive effects while complexity, security concern, adoption cost and top management support have no significant effects on the adoption of IATA e-freight. 


\section{Table 7.}

Analysis of the effect of each factor on the adoption of IATA e-freight

\begin{tabular}{lc}
\hline Independent variable & Adoption (Standardized coefficient) \\
\hline Complexity & 0.097 \\
Security concern & 0.064 \\
Adoption cost & -0.070 \\
Top management support & -0.039 \\
IT competence & $0.206^{* *}$ \\
Trading partner pressure & $0.203^{* *}$ \\
Government policy & $0.353^{* *}$ \\
Competitive pressure & $0.326^{* *}$ \\
$\mathrm{R}^{2}$ & 0.656 \\
Adjusted R & 0.637 \\
F value & 33.437 \\
p-value & 0.000 \\
Durbin Waston statistic & 2.127 \\
\hline
\end{tabular}

Note: $* *$ means achieving the significance level of 0.01 .

\section{Conclusions and suggestions}

The purpose of this study is to investigate how the technology, organization and environment aspects of IATA e-freight affect adoption. The empirical results show that IT competence, trading partner pressure, government policy and competitive pressure that concern air freight forwarders all have significant positive effects on their adoption while complexity, security concern, adoption cost and top management support do not have any significant effect (as shown in Table 8). This means that air freight forwarders' partnerships with trading partners as well as competition with each other and with international rivals can drive their adoption of IATA e-freight.

\section{Table 8.}

Test results of the hypotheses

\begin{tabular}{lr}
\hline \multicolumn{1}{c}{ Hypothesis } & Test results \\
\hline H1: Complexity has a negative effect on the adoption of e-freight. & Not supported \\
H2: Security concern has a negative effect on the adoption of e-freight. & Not supported \\
H3: Adoption cost has a negative effect on the adoption of e-freight. & Not supported \\
H4: Top management support has a positive effect on the adoption of e-freight. & Not supported \\
\hline
\end{tabular}




\subsection{Managerial implications}

While adopting IATA e-freight, air freight forwarders can do so by enhancing their own IT competence (e.g. the need to connect their internal systems with IATA e-freight and to ensure their employees have basic knowledge of IATA e-freight). Also, trading partner pressure is highly influential to air freight forwarders, who must focus on their interactions with trading partners since they play a key intermediary role between shippers and airlines. If airlines intend to adopt IATA e-freight, the pressure they bring as trading partners will make air freight forwarders more interested in following the suit (e.g. airlines must share the benefits brought by IATA e-freight with air freight forwarders). Government policy is also one of the key factors that affect the adoption of IATA e-freight by air freight forwarders. If governments can support air freight forwarders to adopt international projects, the latter will be more willing to do so. Finally, competitive pressure also has a positive effect on the adoption of IATA e-freight. Air freight forwarders approved to register on the Yearbook 2013 of Taiwan's Ministry of Transportation and Communications amounted to a total number of 1,323 and the number of air freight forwarders has grown $10.2 \%$ in last five years. This clearly explains the competitive state between air freight forwarders in Taiwan. If adopting IATA e-freight can increase their market competiveness, air freight forwarders will be more positive about doing so.

Complexity does not have any significant effect on the adoption of IATA e-freight. This is because IATA has increasingly simplified the process of e-freight adoption so that air freight forwarders can get related information easily, making it less complex for them to adopt IATA e-freight. Therefore, complexity is not a key consideration in their adoption. In addition, air freight forwarders are fairly confident about the project, perceiving no great concerns in its security. As learned from our literature review, adopting IATA e-freight also yields an overall investment benefit greater than its cost. Businesses will consider the cost-benefit relationship before they decide whether they will adopt IATA e-freight and will be not deterred by overly high investment cost. 
Therefore, adoption cost in this model does not have any significant effect on adoption. Finally, top management support has also not achieved the significance level possibly because other external factors that air freight forwarders have to consider have indirect effects on their adoption. It is true that top support management is important. Top management can reduce obstacles for companies in the adoption process by promoting the adoption of the project or associated systems as well as education and training across the organization, reducing organizational rigidity and improving knowledge management capabilities. Nevertheless, compared to other external factors, top management support is not a key factor that affects the adoption of the project and associated systems by air freight forwarders.

\subsection{Suggestions}

The first suggestion is that air freight forwarders should enhance their own information facilities and capabilities to support the e-freight project and address possible difficulties during the adoption because introducing the project is a progressive process and does not deliver outcomes immediately. Therefore, the project must be integrated with operating processes. In addition, internal education and training programs should be provided for employees to enrich their expertise for IATA e-freight and deliver expected outcomes. Also, government policy plays a foremost key role in promoting the adoption of IATA e-freight. The existing platform for logistics information services in Taiwan still mainly addresses the business transaction need of shippers and logistics operators. Since the increasingly complex model of international logistics operations requires more versatile logistics information services, government authorities should build an integrated service platform, especially through cloud-based integration of logistics information and services, to increase logistics efficiency and international competitiveness. Air freight forwarders should also discuss with their trading partners (airlines, cargo terminal operators, customs brokers and air freight forwarder associations) regularly or frequently on the promotion of IATA e-freight to share related expertise and introduce cloud-based air cargo information systems. From the commercial point of view, this enables a more rapid understanding of the dynamics in international air cargo markets and effective enhancement of international competitiveness.

Regarding research limitations, the analysis in this study was based on only 149 valid samples. A larger sample size is therefore suggested to further research for better representation of findings. Also, the survey base in this study was limited to air freight forwarders. Further research may extend the base to consigners and airlines to understand 
how different industries address the adoption of IATA e-freight. Moreover, selection of research variables in this study, which was mainly based on the technologyorganization-environment framework, fell short of enumerating all the variables that can affect adoption and could compromise research integrity. Further research may explore more variables that can affect the adoption of IATA e-freight and the introduction of cloud-based air cargo information systems, such as 'organization size', 'knowledge management capability' and 'perceived industry pressure' etc. 


\section{References}

1. Ajzen, I. and Fishbein, M., 1980. Understanding attitudes and predicting social behavior. Englewood Cliffs, N J: Prentice-Hall.

2. Boeing, 2012. World Air Cargo Forecast 2012-2013, Chicago: Boeing.

3. Caldeira, M.M. and Ward, J.M., 2002. Understanding the successful adoption and use of IS/IT in SMEs: an explanation from Portuguese manufacturing industries. Information System Journal, 12(2), 121-152.

4. Chao, C.C., Lirn T.C. and Shang, K.C., 2011. Market segmentation of airline cargo transport. The Service Industries Journal, 33(15-16), 1672-1685.

5. Cheng, J.M.S., Sheen, G.J. and Lou, G.C., 2006. Consumer acceptance of the internet as a channel of distribution in Taiwan-a channel function perspective. Technovation, 26(7), 856-864.

6. Chong, A.Y.L. and Chan, F.T.S., 2012. Structural equation modeling for multi-stage analysis on Radio Frequency Identification (RFID) diffusion in the health care industry. Expert Systems with Applications, 39(10), 8645-8654.

7. Dai, H. and Palvia, P.C. 2008. Mobile Commerce Adoption in China and the United States: A Cross-Cultural Study. Advance in Information System, 40(4), 43-61.

8. Davis, F.D., 1989. Perceived Usefulness, Perceived Ease of Use and User Acceptance of Information Technology. MIS Quarterly, 13(3), 319-340.

9. Fishbein, M. and Ajzen, I. B., 1975. Belief, Attitude, Intention and Behavior: An Introduction to Theory and Research, MA: Addison-Wesley.

10. Gunasekaran, A. and Ngai, A.W.T., 2008. Adoption of e-procurement in Hong Kong: An empirical research. International Journal of Production Economics, 113(1), 159-175. 
11. Hair, J.F., Black, W.C., Babin, B.J., Anderson, R.E. and Tatham, R.L., 2009. Multivariate Data Analysis, 6th Edition. Prentice-Hall, New Jersey.

12. Hoffman, D.L. and Novak, T.P., 1996. Marketing in Hypermedia Computer-Mediated Environments: Conceptual Foundations. Journal of Marketing, 60(3), 50-68.

13. Hsu, P., Krsemer, K.L. and Dunkle, D., 2006. Determinants of e-business use in U.S. firms. International Journal of Electronic Commerce, 10(4), 9-45.

14. Ifinedo, P., 2008. Impacts of business vision, top management support, and external expertise on ERP success. Business Process Management, 14(4), $551-568$.

15. International Air Transport Association (IATA), 2013. e-freight fundamental. Available at:

http://www.iata.org/whatwedo/cargo/e/efreight/Documents/e-freight-fundamentals. pdf (accessed 22 Nov, 2013)

16. International Air Transport Association (IATA), 2013. e-freight Handbook. Available at:

http://www.iata.org/whatwedo/cargo/e/efreight/Documents/e-freight-handbook.pdf (accessed 22 Nov,2013)

17. King, J.L.,Gurbaxani, V., Kraemer, K., Mcfarlan, F.W., Raman, K.S., and Yap, C.S., 1994. Institutional factors in information technology innovation. Information Systems Research, 5(2), 139-168.

18. Lee, S. and Kim, K.J., 2008. Factors affecting the implementation of electronic data interchange in Korea. Computers in Human Behavior, 24(2), 263-283.

19. Li, J., Wang, Y.F., Zhang, Z.M. and C, C.H., 2010. Investigating Acceptance of RFID in Chinese Firms: the Technology-Organization-Environment Framework, In Program for the IEEE International Conference on RFID-Technology and Applications, pp.17-19, Guangzhou, China. 
20. Lian, J.W., Y, D.C. and Wang, Y.T., 2013 An exploratory study to understand the critical factors affecting the decision to adopt cloud computing in Taiwan hospital. International Journal of Information Management, 34(1), 28-36.

21. Lin, H.F., 2013. Understanding the determinants of electronic supply chain management system adoption: Using the technology-organization-environment framework. Technological Forecasting and Social Change, 80(7), 1247-1446

22. Lu C.S., Lai K.H. and Cheng, T.C.E., 2007 Application of structural equation modeling to evaluate the intention of shippers to use internet services in liner shipping. European Journal of Operational Research, 180(2), 845-867.

23. Orlikowski, W.J., 2000 Using Technology and Constituting Structures: A Practice Lens for Studying Technology in Organizations. Organization Science, 11(4), 404-428.

24. Parolia, N., Goodman, S., Li, Y. and Jiang, J.J., 2007. Mediators between coordination and IS project performance. Information Management, 44, 635645.

25. Ramdani, B., Chevers, D. and Williams, D.A., 2013. SMEs' adoption of enterprise applications: A technology-organisation-environment model. Journal of business and Enterprise Development, 20(4), 735-753.

26. Roger, E.M.,2003. Diffusion of Innovation, 5th ed., Free Press, New York.

27. Srinivasan, S.S., Anderson, R. and Ponnavolu, K., 2002. Customer loyalty in e-commerce: an exploration of its antecedents and consequences. Journal of Retiling, 78(1), 41-50.

28. Skyteam cargo, 2011. An introduction on e-freight Available at : http://static.skyteam.com/Global/Cargo\%20Images/e-freight_factfile_2011.pdf (accessed 20 Oct,2013) 
29. Tippins, M. J. and Sohi, R. S., 2003. IT Competence and Firm Performance: Is Organizational Learning a Missing Link? Strategic Management Journal ,24(8), 745-761.

30. Tornatzky, L.G. and Fleischer, M., 1990. The processes of technological innovation. Journal of Technology Transfer, 16(1), 45-46.

31. Wang, Y.M., Wang, Y.S. and Yang, Y.F., 2010. Understanding the determinants of RFID adoption in the manufacturing industry. Technological Forecasting and Social Change, 77(5), 803-815.

32. Wei, T.T., Marthandan, G., Chong, A.Y.L., Ooi, K. B. and Arumugam, S. 2009. What drives Malaysian m-commerce adoption? An empirical analysis. Industrial Management and Data Systems, 109, 370-388.

33. Yang, C.C. and Lu, C.S., 2012. Factors influencing the use intention of port logistics information system by ocean carriers. International Journal Shipping and Transport Logistics, 4(1), 29-48.

34. Yiu, C.S., Grant, K. and Edgar, D., 2007. Factors affecting the adoption of Internet Banking in Hong Kong - implications for the banking sector. International Journal of Information Management, 27(5), 336-351.

35. Zhang, C., Cui, L, Huang, L. and Zhang, C., 2007. Exploring the Role of Government in Information Technology Diffusion: An Empirical Study of IT Usage in Shanghai Firms, In Organizational Dynamics of Technology-Based Innovation: Diversifying the Research Agenda, pp.393-407, Springer, Boston.

36. Zhu, K., Dong, S., Xu, S.X. and Kraemer, K.L., 2006. Innovation diffusion in global contexts: determinants of post-adoption digital transformation of European companies. European Journal of Information Systems, 15(6), 601-616.

37. Zhu, K., Kraemer, K.L. and $\mathrm{Xu}, \mathrm{S}$. 2003. E-business adoption by European firm: A cross-country assessment of the facilitators and inhibitors. European Journal Information System, 12(4), 251-268. 